\title{
Development of a Drink Type Infusion From Coffee Pulp (Arabia coffea) Lempira Variety of Honduras
}

\author{
Jhunior Abrahan Marcia Fuentes ${ }^{1,2}$, Ricardo Santos Alemán ${ }^{3}$, Leonardo Antonio Chavarría ${ }^{4}$, \\ Ingris Mary Varela Murillo ${ }^{1}$, Noreyda Patricia Alvarado ${ }^{1} \&$ Ismael Montero Fernández $^{5}$ \\ ${ }^{1}$ Facultad de Ciencias Tecnológicas, Universidad Nacional de Agricultura, Catacamas, Honduras \\ ${ }^{2}$ Facultad de Farmacia y Alimentos, Universidad de La Habana, Cuba \\ ${ }^{3}$ Louisiana State University, USA \\ ${ }^{4}$ Facultad de Ingeniería Química, Universidad Nacional de Ingeniería, Managua, Nicaragua \\ ${ }^{5}$ Departamento de Química Orgánica e Inorgánica, Escuela Politécnica, Universidad de Extremadura, Cáceres, \\ Spain \\ Correspondence: Jhunior Abrahan Marcia Fuentes, Facultad de Ciencias Tecnológicas, Universidad Nacional de \\ Agricultura, Carretera a Dulce Nombre de Culmí, Km 215, Barrio El Espino, Catacamas, Olancho, Honduras. \\ E-mail: juniorabrahamm@yahoo.com
}

Received: October 14, 2019

doi:10.5539/jas.v12n1p209
Accepted: November 18, 2019 Online Published: December 15, 2019

URL: https://doi.org/10.5539/jas.v12n1p209

\begin{abstract}
This work aimed to develop an infusion type beverage from Lempira coffee pulp for human consumption. Samples from the Honduran Coffee Institute IHCAFE were used. According to the results obtained from the sensory analysis, it was determined that $70.75 \%$ of the evaluators prefer the beverage made with mature grains, given that a balance in taste and acidity is obtained. As for the mass concentration of the packaged content, $60 \%$ of the universe of tasters prefer a concentration of $1.6 \mathrm{~g}$ of dried pulp per cup. Regarding the type of grinding of the grain, it was determined that $80 \%$ of the tasters prefer coarse grinding (701 to $900 \mu \mathrm{m}$ ), describing it as an extremely pleasant product in its flavor and color, with shades of Jamaica, tamarind and nuts. Checking that with this particle size there is a greater release of flavors and maintains a balance in terms of aromas, however in fine particles ( 350 to $500 \mu \mathrm{m}$ ), their fragrances stand out, but negatively affects their taste and the high sedimentation rate. Therefore, it was concluded that the quality of the infusion drink from coffee pulp is influenced by the type of grinding used for its preparation.
\end{abstract}

Keywords: sustentability, quality, type of grinding

\section{Introduction}

Coffee is the most important export product in Honduras, being the largest exporter in the Central American region; the third in Latin America and the fifth worldwide, making large contributions to the Gross Domestic Product of the country that oscillates around $35 \%$, benefiting about 120 thousand families and generating more than one million direct and indirect jobs (IHCAFÉ, 2017). Hunger will be one of the problems that humanity will face in the future, being that, according to the FAO between the year 2000-2030, the world will have to increase the per capita production of meat by $20 \%$, estimating that in the year 2030 , bird production should grow by around $40.4 \%$, bovine $12.70 \%$, fish by $19 \%$ and pig by $20 \%$, high percentages at an accelerated rate of growth.

The pulp is the first bioproduct that is obtained in the processing of the coffee fruit, according to FAO data, globally the residues of the coffee industry have been estimated at approximately 22 million tons of coffee pulp and 8.6 million tons of mucilage, these bioproducts are discharged into rivers and cause pollution (Ulloa Rojas et al., 2002).

In the coffee industry, only $9.5 \%$ of the weight of the fresh fruit is used in the preparation of the beverage and $90.5 \%$ is in the form of waste. The pulp is the most voluminous part of the coffee bean, it represents between 40 and $56 \%$ by weight of this, in addition to containing water in $20 \%$, husk in $4.5 \%$ and mucilage in $16 \%$ (Coronel \& Marín, 2010). The pulp presents a great variety of alternatives to be recycled in its entirety, including: 
transformation into humus from worm crops and organic fertilizer production, as well as the development of new infusion-type products and cold drinks (Restrepo, 2015).

In the preparation of infusions, the particle size of the coffee pulp is important, since according to its granulometry a perfect extraction is determined, obtaining a greater number of properties than we could obtain from an entire pulp. The objective of this research is to develop an infusion type beverage from coffee pulp of the Lempira variety produced in Honduras for human consumption.

\section{Material and Methods}

\subsection{Local}

The coffee pulp was harvested on the farms of Labor Ocotepeque and Caiquín Lempira (Honduras), affiliated with IHCAFE at a height of 1600 meters above sea level and an average temperature of $20 \pm 10^{\circ} \mathrm{C}$.

The variety of coffee used was Lempira, collected in mature maturity.

\subsection{Preparation of the Infusion Type Drink}

It began with the collection of cherry coffee samples, verifying that the cherries were at their optimum ripeness point in the tree. They were deposited in a container with five liters of water for the flotation of the dried grains and to select the type of maturation. Subsequently, at 3 hours after harvesting, the coffee was pulped mechanically. The pulp that was obtained was deposited in sterile plastic bags to protect it from environmental contamination. The pulp was dried in dome-type solar dryers at a temperature of $40{ }^{\circ} \mathrm{C}$ and relative humidity of $60 \%$, times and temperatures were controlled, the humidity of the sample was $3.5 \%$. Finally, coffee pulp was ground in an automatic electric Cuisinart coffee bean mill, consisting of three types of grinding: fine (350 to 500 $\mu \mathrm{m})$, medium (501 to $700 \mu \mathrm{m})$ and coarse (701 to $900 \mu \mathrm{m})$.

\subsection{Physical-Chemical Characterization}

The physicochemical characterization was made from a representative sample of $1000 \mathrm{~g}$ of sample for each variety, randomly segmenting into 10 experimental units of $100 \mathrm{~g}$ of homogenized coffee pulp.

For the determination of humidity, samples were taken in triplicate of $5 \mathrm{~g}$ in a porcelain capsule (of known mass), then the sample was placed in the P-SELECTR model DIGITRONIF-TFT oven at three test temperatures of $40{ }^{\circ} \mathrm{C}, 50{ }^{\circ} \mathrm{C}$ and $60{ }^{\circ} \mathrm{C}$ and three drying times of $420 \mathrm{~min}, 360 \mathrm{~min}$ and $300 \mathrm{~min}$. With the help of a clamp, the capsule was removed and allowed to stand for $30 \mathrm{~min}$ in a Thermo Scientific drying chamber at medium temperature, the weights were subsequently taken, and the moisture content of the samples was determined by mass difference (AOAC, 2009).

To determine ashes, $25 \mathrm{~g}$ of triplicate sample in crucibles of known mass were weighed on an analytical scale, subsequently fused in a Thermo Scientific HERATHERM model flask at a temperature of $550 \pm 100{ }^{\circ} \mathrm{C}$ for $1.5 \mathrm{~h}$ until all the organic matter was incinerated and only the inorganic compounds were left, then with the help of a clamp the capsule was removed and allowed to stand for $30 \mathrm{~min}$ in a Thermo Scientific drying chamber at medium temperature (AOAC, 2009). The total ash content was calculated by mass difference following the formula proposed by Zumbado (2004).

For the determination of the $\mathrm{pH}$, a digital $\mathrm{pH}$ meter WATER PROOF model PC-Tester was used, which was calibrated with buffer solution of $\mathrm{pH} 4$ and $\mathrm{pH}$ 7. In the sample preparation $250 \mathrm{ml}$ of distilled water was used at temperature of the medium and $6 \mathrm{~g}$ of coffee pulp concentrate, the mixture was homogenized by stirring for 20 $\mathrm{min}$ at $30 \mathrm{rpm}$, in a Vortex Gene 2, Scientific Industries brand. The $\mathrm{pH}$ meter was placed in the solution, for 2 min, and the triplicate reading was taken.

Degrees Brix: were determined by the refractometry technique, from a Boeco brand refractometer with a scale of 0 to 320 Brix. A homogenized sample of $6 \mathrm{~g}$ of coffee pulp concentrate and $250 \mathrm{ml}$ of distilled water was taken in triplicate, once the solution was obtained, it was filtered and particles in suspension were removed, finally reading.

\subsection{Sensory Analysis}

The sensory analysis determined the degree of acceptability of the attributes (color, aroma and flavor) for each level of grinding, performing 7-point hedonic tests with specialized expert judges, following the regulations proposed by Espinosa (2014). 


\subsection{Microbiological Analysis}

According to the RTCA standard (2018), for the microbiological analysis, total bacterial count, yeast count, total colyforms, faecal coliforms, E. coli, Salmonella spp. These analyzes were carried out in the Sanitara de Salud Region, in Juticalpa, Olancho, Honduras.

\section{Results and Discussion}

\subsection{Physicochemical Analysis}

The average values of the moisture content present in the dried coffee pulp of the Lempira variety are shown in Table 1. These results highlight the importance of drying time optimization at different temperatures ranging between $40{ }^{\circ} \mathrm{C}$ and $60{ }^{\circ} \mathrm{C}$ with humidity percentages less than $10 \%$. Classifying this product as a stable food because of its low moisture content and water activity.

Table 1. Moisture percentage of coffee pulp as a base for infusion

\begin{tabular}{lll}
\hline Time $(\min )(\mathrm{n}=3)$ & Temperature $\left({ }^{\circ} \mathrm{C}\right)(\mathrm{n}=3)$ & Moisture $(\%)(\mathrm{n}=3)$ \\
\hline 420 & 40 & 9.5 \\
360 & 50 & 7.9 \\
300 & 60 & 6.7 \\
\hline
\end{tabular}

Figure 1 shows the results from the quantification of ash that was made to two samples of dehydrated coffee pulp from IHCAFE in the department of Ocotepeque (Sample A) and Lempira (Sample B). Obtaining results of $27.9 \%$ and $27.5 \%$ respectively, being sample $\mathrm{A}$, who presented the highest mineral content.

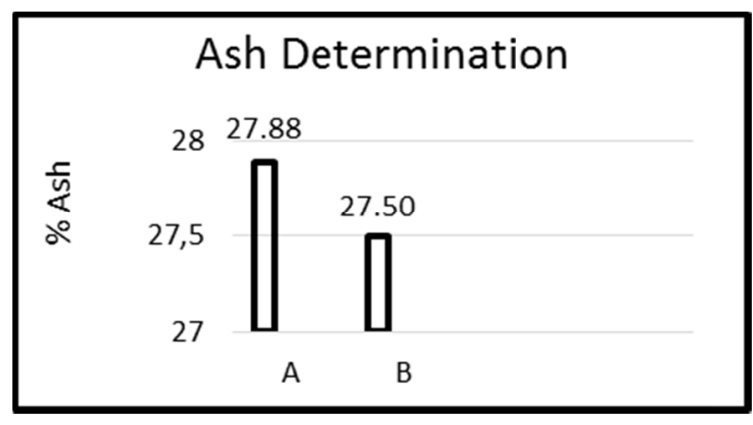

Figure 1. Ashes Quantification

The physicochemical parameters for the coffee samples are collected. The average $\mathrm{pH}$ of this drink is $4.25 \%$ with a concentration of $1.36^{\circ}$ Brix at a temperature of $27.42{ }^{\circ} \mathrm{C}$ for sample A and that the average $\mathrm{pH}$ of sample $\mathrm{B}$ is $4.3 \%$ with a concentration $1.34{ }^{\circ} \mathrm{Brix}$ at a temperature of $27.42{ }^{\circ} \mathrm{C}$. Therefore there is no significant difference between samples.

\subsection{Sensory Analysis}

Table 2 shows the results of sensory analysis carried out by IHCAFE expert judges, that the infusion drink from dehydrated coffee pulp has a higher percentage of acceptance in color, aroma and flavor with a grain size of 6 $\mathrm{mm}$, There are significant differences between the various granulometries $(\mathrm{P}<0.005)$.

Table 2. Sensory analysis

\begin{tabular}{ll}
\hline Grinding level & Median \\
\hline Fine 2 & 0.75 \\
Half 4 & 22.818 \\
Gross 6 & 75 \\
\hline
\end{tabular}




\subsection{Microbiological Analysis}

Table 4 shows, according to microbiological analysis, that the parameters of colony forming units of bacteria and fungi are below the RTCA norm, while showing an absence of E. coli and Salmonella spp.

Table 4. Analysis of aerobic mesophilic microorganisms

\begin{tabular}{lll}
\hline Test & Result & Method \\
\hline Bacteria count & $8000 \mathrm{UFC} / \mathrm{g}$ & Petrifilm for anaerobic cointing \\
Fungus count & $1500 \mathrm{UFC} / \mathrm{g}$ & Petrifilm and cast and Mold Count plate \\
Total Coliforms & $*<10 \mathrm{UFC} / \mathrm{g}$ & Petrifilm Coliformes $/ E$. coli \\
Fecal Coliforms & $*<10 \mathrm{UFC} / \mathrm{g}$ & Petrifilm Coliformes \\
\hline
\end{tabular}

\section{Conclusions}

The pulp is a byproduct of coffee bean that is not being used by the food industry and generates environmental pollution. Based on the results of this research, they suggest the use of pulp for the production of infusion drinks.

The quality of this drink is influenced by the particle size, since a coarse ground of $6 \mathrm{~mm}$ granulometry offers greater sensory qualities in terms of taste, aroma and color. However, the possibility of inactivating the present tannins should be evaluated, in order to take advantage of the chemical properties of this drink, while a toxicological analysis should be addressed to rule out toxicity.

\section{References}

AOAC (Association of Official Analytical Chemist). (2009). Methods of Analysis of the Association of Official Analytical Chemist International (p. 152). Washington, USA.

Coronel, M., \& Marín, A. (2010). Estudio del café especial ecuatoriano. Proyecto final de Máster para la obtención del título de Máster Internacional en Nutrición y Dietética (p. 60). Quito, Ecuador.

Espinosa, J. (2014). In F. Varela (Ed.), Análisis Sensorial (p. 400). Facultad de Farmacia y Alimentos, Universidad de la Habana, La Habana, Cuba.

IHCAFE (Instituto Hondureño del Café). (2017). Proyección alza en producción de café en América Central. Tegucigalpa, Honduras.

Restrepo, J. (2015). Caracterización fisica y química de los frutos de café. Retrieved from https://es.slideshare.net/ anamasalazar/quimica-y-fisica-del-cafe

RTCA (Reglamento Técnico Centroamericano). (2018). Alimentos, Criterios microbiológicos para la inocuidad, RTCA 67.04.50:17 (pp. 11-14). San José, Costa Rica.

Ulloa Rojas, J. B., Verreth, J. A. J., van Weerd, J. H., \& Huisman, E. A. (2002). Effect of different chemical treatments on nutricional and antinutritional properties of coffee pulp. Animal Feed Science and Technology, 99(1-4), 195-204. https://doi.org/10.1016/S0377-8401(02)00050-0

Zumbado, H. (2004). Análisis Químico de Alimentos. In F. Varela (Ed.), Metodos Clasicos (p. 437). La Habana, Cuba. Retrieved from http://beduniv.reduniv.edu.cu/fetch.php?data $=200 \&$ type $=p d f \& i d=2813 \& d b=0$

\section{Copyrights}

Copyright for this article is retained by the author(s), with first publication rights granted to the journal.

This is an open-access article distributed under the terms and conditions of the Creative Commons Attribution license (http://creativecommons.org/licenses/by/4.0/). 